Pak. j. sci. ind. res. Ser. A: phys. sci. 2018 61A(3) 126-131

\title{
Studies of Chemical Constituents from Eremostachys loasifolia
}

\author{
Muhammad Imran ${ }^{a b *}$, Uzma Rasheed Mughalc, Muhammad Iqbald, Riaz Hussain ${ }^{\mathrm{e}}$, \\ Wasif Iqbal ${ }^{\mathrm{f}}$, Rafy Yaqeen ${ }^{\mathrm{g}}$ and Sadia Ferheen ${ }^{\mathrm{g}}$ \\ ${ }^{a}$ Department of Chemistry, Ghazi University Dera Ghazi Khan, Pakistan \\ ${ }^{\mathrm{b} S}$ School of Chemistry, University of Bristol, United Kingdom \\ 'Departmentof Chemistry, GC University Faisalabad, Layyah Campus, Pakistan \\ dDepartment of Biochemistry\& Biotechnology, The Islamia University of Bahawalpur, Bahawalpur, Pakistan \\ ${ }^{e}$ Departmentof Chemistry, University of Education Lahore, D. G. Khan Campus, Pakistan \\ ${ }^{\mathrm{f}}$ Science of Dental Materials, Mohammad Bin Qasim Medical and Dental College, Port Qasim, Karachi, Pakistan \\ ${ }^{g}$ PCSIR Laboratories Complex, Karachi-75280, Pakistan
}

(received November 9, 2017; revised August 8, 2018; accepted August 15, 2018)

\begin{abstract}
The chemical constituent analysis on the whole plant Eremostachys loasifolia (Family: Lamiaceae) resulted 13 compounds of flavonoids class for the first time from this species namely Loasifolin (1), Eremoside A (2), Eremoside B (3), Kaempferol (3,4',5,7-tetrahydroxyflavone) (4), 5-Hydroxy-6,7,8,4'tetramethoxyflavone (5), 5-Hydroxy-3',4',6,7,8-pentamethoxyflavone (6), Apigenin (4',5,7-trihydroxyflavone) (7), Luteolin (3',4',5,7-tetrahydroxyflavone) (8), Apigenin 7-O- $\beta$-D-glucopyranose (9) 4-Methyl Kaempferol (3,5,6-trihydroxy-4methoxy flavone) (10) 5-Hydroxy-7,4-dimethoxy flavones (11), 6,7-Dimethoxy-4,5hydroxyflavone (12), 3,5,7-Trihydroxy-3',4'-dimethoxyflavone (13). Further, all isolated compounds showed antioxidant activity. The structures of isolated compounds were determined using different spectroscopic techniques including NMR, UV/Vis., IR and MS.
\end{abstract}

Keywords: Eremostachys loasifolia, antioxidant activity, flavonoids

\section{Introduction}

The plant genus Eremostachys is member of the family Labiatae (Lamiaceae) which comprises of eighty species and distributed in mostly Afghanistan and Russia region (Li and Hedge, 1995). Plants of this genus are used for medicinal purpose in China and Asia for the purpose of local analgesic, for the treatment of allergies, headache, liver diseases and skin diseases (Ali and Nasir, 1990). The genus compounds also show strong antidepressant activity, cytotoxic activity and free radical scavenging activity (Delazar et al., 2004a; 2004b). Eremostachys loasifolia is one of the important species of this genus that can be found in Balochistan, and in the northern province of Pakistan. The previous study of the genus showed the presence of essential diterpenes, iridoids, fatty acids, oils, flavonoids, and aromatic glucosides (Modaressi et al., 2009; Muhammad et al., 2006; Said et al., 2002). In this plant previously, no systematic pharmacological studies have so far been carried out and therefore chemical analysis of this species was studied because of its medicinal importance. From the results of present experimental work thirteen flavonoids isolated for the first time from E. loasifolia. The com-

*Author for correspondence:

E-mail: imranchemist@gmail.com pounds are Loasifolin (1), Eremoside A (2), Eremoside B (3), Kaempferol (3,4',5,7-tetrahydroxyflavone) (4), 5-Hydroxy-6,7,8,4'-tetramethoxyflavone (5), 5-Hydroxy$3^{\prime}, 4^{\prime}, 6,7,8$-pentamethoxyflavone (6), Apigenin (4',5,7trihydroxyflavone) (7), Luteolin (3',4',5,7-tetrahydroxyflavone) (8), Apigenin 7-O- $\beta$-D-glucopyranose (9) 4'Methyl Kaempferol (3,5,6-trihydroxy-4methoxy flavone) (10) 5-Hydroxy-7,4-dimethoxy flavones (11), 6,7-Dimethoxy-4,5-hydroxyflavone (12) and 3,5,7-Trihydroxy3',4'-dimethoxyflavone (13). The structures of all isolated compounds are showed in Fig. 1.

\section{Materials and Methods}

The Al precoated sheets (Merck diameter $20 \times 20 \mathrm{~cm}$,) with silica gel were used for TLC and stationary phase in glass column for chromatographic (230-400 and 80200 mesh size) silica gel was used. Hitachi UV-3200 spectrometer for the TLC spot location determination was used under wavelength at 254 and 366. Polarimeter DIP-360 JASCO was used for the determination of optical rotations of the compounds. Infra Red 460 Shimadzu spectrometer were recorded for IR. JMSHX-110 mass spectrometers were used for EI-MS and HR-EI-MS measurement, Bruker spectrometers (400 $\mathrm{MHz}$ ) for the the proton-NMR, ${ }^{13} \mathrm{C}-\mathrm{NMR}$. The activity 
i.e., antioxidant of all isolated compounds 1-13 was carried out by the same protocol as described in discussion (Wavy et al., 2003; Yoshi Rawa et al., 2002).

Plant material. Eremostachys loasifolia complete plant was collected from Lakpass, Quetta Valley, Balochistan, Pakistan and identified by Balochistan University, Plant Taxanomist, where No. el. Rbt. 01. 2005 (specimen voucher) was alloted in the departmental herbarium.

Extraction, fractionation and purification. Freshly collected Eremostachys loasifolia plant $(20 \mathrm{~kg})$ was dried and extracted at r.t with ethanol $(4 \times 30 \mathrm{~L}, 08$ days each). $750 \mathrm{~g}$ residue was attained from these combined ethanolic portion after reduced pressure evaporation $(400 \mathrm{~g})$. The ethanolic plant residue $750 \mathrm{~g}$ was dissolved in water $(500 \mathrm{~mL})$ and further extracted into petroleum ether $(80 \mathrm{~g}), \mathrm{CH}_{2} \mathrm{Cl}_{2}(65 \mathrm{~g})$, ethyl acetate (105 g), $n$-butanol (164 g) and $\mathrm{H}_{2} \mathrm{O}$ soluble portion.

Ethyl acetate (105 g) soluble portion was exposed to chromatography separation FCC as stationary phase silica gel (different mesh size) and mobile phase petroleum ether, chloroform and methanol depending upon polarity of constituents. From first large column five major fractions obtained namely E1 to E-5. The E1 fraction was chromatographed over FCC silica gel and obtained three fractions (A-1 to A-3). The (4.0:6.0) petroleum ether: $\mathrm{CHCl}_{3}$ fraction A-1 on further chromatography gives (4).

The E-2 portion (7.0:3.0) petroleum ether- $\mathrm{CHCl}_{3}$ was finally purified by $\mathrm{CC}$ via solvent (2.3:7.7) system petroleum ether $-\mathrm{CHCl}_{3}$ giving compounds 5 and $\mathbf{6}$. The petroleum ether- $\mathrm{CHCl}_{3}$ (1.0:9.0). The portion E3 was chromatography using eluting system (1.5:8.5) with petroleum ether $-\mathrm{CHCl}_{3}$ to pay for 7 and two compounds mixture that was separated by preparative TLC (1.8: 8.2) solvent petroleum ether $-\mathrm{CHCl}_{3}$ to give compound 8 and 9 . The (9.8:0.2) $\mathrm{CHCl}_{3}: \mathrm{MeOH}$ fraction A-2, gives compound 10. The third fraction hexane and chloroform (8.5:1.5) upon further FCC analysis gives compound 11. The fraction E-4 obtained from (9.5:0.6) Chloroform-MeOH was chromatographed using eluent system (9.3:0.7) Chloroform-MeOH to afford 12 (9 $\mathrm{mg})$ and (9.2:0.8) 13 (11 mg).

The fraction E-5, obtained from pure chloroform was subjected to FCC give rise to three sub fractions. The first fraction further chromatographed by $(7.5: 2.5)$ of chloroform: methanol mobile phase solvent system gives pure compound $\mathbf{1}$. The second portion $(9.8: 0.2)$ chloroform:methanol was re-chromatographed over FCC and eluted with chloroform:methanol to obtain (2) and (3).

Loasifolin (1), Eremoside A (2), Eremoside B (3), for these new compounds spectroscopic data are already published (Mughal et al., 2010) but activity are reported first time. The data including both physical and spectral of compounds 4-13 were comparable with the literature values (Imran et al., 2012; Ahmed et al., 2006; Sadikum et al., 1980; Redalli et al., 1980; Dawson et al., 1966).

\section{Results and Discussion}

The chemical constituents were extracted with ethanol and then crude extract (ethanol) was suspended in water and partitioned into petroleum ether, $\mathrm{CH}_{2} \mathrm{Cl}_{2}, \mathrm{EtOAc}$, $n$ - $\mathrm{BuOH}$ and water fractions on the basis of respective solubility. Further analysis especially chromatographic were performed on EtOAc portion because of its strong crude activity. Series of column and flash chromatographic analyses were performed on the EtOAc soluble part and as a result $\mathbf{1 3}$ compounds separated and identified. These are namely, Loasifolin (1), Eremoside A (2), Eremoside B (3), Kaempferol (3,4',5,7-tetrahydroxy-flavone) (4), 5-Hydroxy-6,7,8,4'-tetramethoxyflavone (5), 5-Hydroxy-3',4',6,7,8-pentamethoxy-flavone (6), Apigenin (4',5,7-trihydroxy-flavone) (7), Luteolin (3',4',5, 7-tetrahydroxy-flavone) (8), Apigenin 7-O- $\beta$ D-glucopyranose (9) 4-Methyl Kaempferol (3,5,6trihydroxy-4-methoxy-flavone) (10) 5-Hydroxy-7,4'dimethoxy-flavones (11), 6,7-Dimethoxy-4',5-hydroxyflavone (12), 3,5,7-Trihydroxy-3',4'-dimethoxy-flavone (13). The purified flavonoids showed antioxidant properties (Table 1). The structures of all isolated compounds were shown in Fig. 1.

The structures of compounds $\mathbf{1 - 3}$ were already published in detail with our previous articles. 5 compound Kaempferol (4) was obtained as light yellow powder from EtOAc-soluble part. It UV $\left(\lambda_{\max }\right)$ spectrum and IR $\left(\mathrm{cm}^{-1}\right)$ spectrum absorption bands are the typical flavonoidal nature. The HREI-MS showed the molecular ion peak at $m / z 286$ consistent with the formula $\mathrm{C}_{15} \mathrm{H}_{10} \mathrm{O}_{6}$. Furthermore, the ${ }^{1} \mathrm{H}$ NMR spectrum indicated the presence of para-substituted benzene ring with $\mathrm{AA}^{\prime} \mathrm{BB}^{\prime}$ pattern. The ${ }^{13} \mathrm{C}$ NMR (BB and DEPT) spectra showed the characteristic signals of a flavonoidal skeleton. On the basis of these evidences and comparison with published data its named as Kaempferol. 
Compound (5) was obtained as yellow crystalline powder from the chloroform portion. It gave violet colour with $\mathrm{FeCl}_{3}$ for a phenol. The UV $\left(\lambda_{\max }\right)$ spectrum and IR $\left(\mathrm{cm}^{-1}\right)$ spectrum showed absorption bands of aromatic moieties. The EI-MS showed the fragment peaks at $\mathrm{m} / \mathrm{z}$ 358. The HREI-MS showed the molecular ion peak at $m / z 358$ indicating the molecular formula $\mathrm{C}_{19} \mathrm{H}_{18} 0_{7}$. From ${ }^{1} \mathrm{H}-\mathrm{NMR}$ spectrum data presence of para substituted ring revealed. Furthermore the presence of four methoxy moieties were also observed at $\delta 3.84$, 3.87, 3.90 and 3.93. The ${ }^{13} \mathrm{C}-\mathrm{NMR}$ (BB and DEPT) spectra showed well resolved total nineteen carbon signals comprising four methyl, five methine and ten quaternary carbon atoms.

Compound (6) was obtained as yellow solid from the EtOAc soluble part. It gave violet colour with $\mathrm{FeCl}_{3}$ for a phenol. The UV $\left(\lambda_{\max }\right)$ spectrum and IR $\left(\mathrm{cm}^{-1}\right)$ spectrum absorption bands indicating aromatic skeleton. The high resolution EI-MS showed the molecular ion peak at $\mathrm{m} / \mathrm{z} 388$ which deduced the molecular formula $\mathrm{C}_{20} \mathrm{H}_{20} 0_{8}$. Its ${ }^{1} \mathrm{H}-\mathrm{NMR}$ showed at the aromatic(ABX system) region i.e., of five methoxyl protons and four protons in the. The ${ }^{13} \mathrm{C}$-NMR showed well resolved total twenty signals comprising of 11 quaternary carbon, 4 methine and 5 methyl atoms.

Compound (7) was obtained as pale yellow form from the $\mathrm{CH}_{3} \mathrm{Cl}$ portions showing violet colour with $\mathrm{FeCl}_{3}$

Table 1. Antioxidant activity of compounds 1-13

\begin{tabular}{lll}
\hline \hline Compound & $\begin{array}{l}\text { DPPH assay } \\
\left(\mathrm{IC}_{50}\right)^{\mathrm{a}}\end{array}$ & $\begin{array}{l}\text { Cytochrome-c reduction } \\
\text { assay }\left(\mathrm{IC}_{50}\right)^{\mathrm{a}}\end{array}$ \\
\cline { 2 - 3 } & & $(\mu \mathrm{M})$ \\
\hline 1 & 25.3 & 24.1 \\
2 & 33.1 & 26.5 \\
3 & 32.5 & 25.1 \\
4 & 24.2 & 23.2 \\
5 & 26.1 & 24.2 \\
6 & 26.3 & 24.1 \\
7 & 23.9 & 23.2 \\
8 & 24 & 23.5 \\
9 & 25.7 & 23.9 \\
10 & 25.1 & 23.5 \\
11 & 25.9 & 24.5 \\
12 & 26.1 & 25.2 \\
13 & 24.8 & 23.1 \\
Gallic acid $^{\mathrm{b}}$ & 20.9 & 17.3 \\
\hline \hline
\end{tabular}

${ }^{\mathrm{a}}=$ results in $\mathrm{IC}_{50}$ values $(\mu \mathrm{M}){ }^{\mathrm{b}}=$ positive control.

All analysis were average of four experiments. for a phenol. The UV $\left(\lambda_{\max }\right)$ spectrum and IR $\left(\mathrm{cm}^{-1}\right)$ spectrum showed presence of flavone moieties. The molecular ion peak observed at $\mathrm{m} / \mathrm{z} 270$ showing the molecular formula $\mathrm{C}_{15} \mathrm{H}_{10} \mathrm{O}_{5}$. The para-disubstituted benzene ring as an $\mathrm{AA}^{\prime} \mathrm{BB}^{\prime}$ pattern observed in its ${ }^{1} \mathrm{H}$ NMR spectrum. Its ${ }^{13} \mathrm{C}$-NMR spectra showed the typical carbon pattern of flavonoid.

The compound (8) was obtained as light yellow powder from the $\mathrm{CH}_{3} \mathrm{Cl}$ portions giving violet colour with $\mathrm{FeCl}_{3}$ for a phenol. The UV $\left(\lambda_{\max }\right)$ spectrum and IR $\left(\mathrm{cm}^{-1}\right)$ spectrum absorption bands absorption bands of conjugated aromatic system. The MS spectra in hard ionization mode showed the molecular ion peak at $\mathrm{m} / \mathrm{z}$ 286 which deduced the molecular formula $\mathrm{C}_{15} \mathrm{H}_{10} \mathrm{O}_{6}$. The tri-substituted ring pattern was observed in its ${ }^{1} \mathrm{H}$ NMR spectrum. The ${ }^{13} \mathrm{C}-\mathrm{NMR}$ showed fifteen carbon 15 signals consisting of 9 quaternary and 6 methine carbon atoms.

Compound (9) was obtained as a yellow amorphous powder. The UV $\left(\lambda_{\max }\right)$ spectrum and IR $\left(\mathrm{cm}^{-1}\right)$ absorption bands were similar to flavone. The MS gives M.F $\mathrm{C}_{21} \mathrm{H}_{21} \mathrm{O}_{10}$ showing peak at $\mathrm{m} / z$ 433. The chelated hydroxyl group observed in its ${ }^{\mathrm{I}} \mathrm{H}-\mathrm{NMR}$ spectrum because of $\mathrm{H}$-bonding. The sugar moiety in $\beta$ configuration were also observed. The ${ }^{13} \mathrm{C}$-NMR spectra showing twenty one carbon signal out of these 1 methylene 12 methine and 8 quaternary carbons.

Compound (10) was obtained as a light yellow solid. Its mass spectra of showed molecular ion peak at $\mathrm{m} / \mathrm{z}$ 300 with the molecular formula $\mathrm{C}_{16} \mathrm{H}_{12} \mathrm{O}_{6}$. The UV $\left(\lambda_{\max }\right)$ spectrum and IR $\left(\mathrm{cm}^{-1}\right)$ spectrum absorption bands absorption bands of flavone system. The total six signals of $\mathrm{H}$ with ring $\mathrm{B}$ is symmetrical, free methoxyl group at position $\mathrm{C}-4$ in the downfield region in its ${ }^{1} \mathrm{H}-\mathrm{NMR}$ spectra.

Compound (11) was obtained as a light yellow solid. Its mass spectra of showed molecular ion peak at $\mathrm{m} / \mathrm{z}$ 298 with M.F $\mathrm{C}_{17} \mathrm{H}_{14} \mathrm{O}_{5}$. The UV $\left(\lambda_{\max }\right)$ spectrum and IR $\left(\mathrm{cm}^{-1}\right)$ spectrum absorption bands absorption bands of flavone skeleton. The seven signals of $\mathrm{H}$ in the downfield region i.e., aromatic in its ${ }^{1} \mathrm{H}-\mathrm{NMR}$ spectra.

The EI-MS data of compound (12) showed molecular ion peak at $m / z$ 314. Its molecular formula observed in HREI-MS 314 with the M.F $\mathrm{C}_{17} \mathrm{H}_{14} \mathrm{O}_{6}$. The UV $\left(\lambda_{\max }\right)$ spectrum and IR $\left(\mathrm{cm}^{-1}\right)$ spectrum absorption bands absorption bands of benzene rings. The six signals of $\mathrm{H}$ in the downfield region i.e., aromatic in its ${ }^{1} \mathrm{H}-\mathrm{NMR}$ spectra. 
Compound (13) showed the UV $\left(\lambda_{\max }\right)$ spectrum and IR $\left(\mathrm{cm}^{-1}\right)$ spectrum absorption bands absorption bands of aromatic species. Its EI-MS confirmed M.F as $\mathrm{C}_{17} \mathrm{H}_{14} \mathrm{O}_{7}$ showing mass peak at $\mathrm{m} / z$ 330. The two $\mathrm{OCH}_{3}$ signals and five $\mathrm{H}$ present in the aromatic region in its ${ }^{1} \mathrm{H}-\mathrm{NMR}$. The 17 carbon signals were observed in ${ }^{13} \mathrm{C}$-NMR spectra including ten quaternary five methine, and two methyl carbons. All the physical and spectral data of isolated compounds correspondence with the published data (Imran et al., 2012; Ahmed et al., 2006; Sadi Rum et al., 1980; Redalli et al., 1980; Dawson et al., 1966).

Antioxidant activity of compound 1-13. The determination of antioxidant activity of compounds 1-13, DPPH followed by cytochrome-c-reduction tests were followed. The TPA-induced (HL-60 cell culture system) free radical formation with the positive control and showed free radical scavenging activity in the DPPH assay (Wavg et al., 2003; Yoshi Rawa et al., 2002). All isolated compounds showed significant antioxidant activity compared against standards (Table 1).

Spectral data. Kaempferol (3,4',5,7-tetrahydroxyflavone) (4). EI-MS m/z:286; HREI-MS: $m / z 286.0488$ $[\mathrm{M}]^{+}$(calcud. for $\mathrm{C}_{15} \mathrm{H}_{10} \mathrm{O}_{6}, 286.0474$ ). Light yellow powder (19 mg) M. P: $277^{\circ} \mathrm{C}$; UV (MeOH) 213, 267, 337; IR (KBr) $\cup_{\max } \mathrm{cm}^{-1}: 3417,2928,1661,1611$ and $1178 ;{ }^{1} \mathrm{H}$ NMR $\left(500 \mathrm{MHz} \mathrm{CD}_{3} \mathrm{OD}\right)(\delta \mathrm{ppm}):(\mathrm{J}$ in $\mathrm{Hz})$ 6.95 (d, H each, $J=8.6, \mathrm{H}^{-3} 5^{\prime}$ ), 6.37 (d, H, $J=2.1, \mathrm{H}-$ 8), 8.06 (d, $1 \mathrm{H}$ each, $\left.J=8.6, \mathrm{H}-2^{\prime} 6^{\prime}\right), 6.18$ (d, H, $J=$ 2.0, H-6).

5-Hydroxy-6,7,8,4'-tetramethoxyflavone (5). EI-MS $\mathrm{m} / \mathrm{z}$ (rel. int.): 358; HREI-MS m/z: 358.1043 (calcud. for $\left.\mathrm{C}_{19} \mathrm{H}_{18} \mathrm{O}_{7}, 358.1049\right)$. Yellowish solid (23); M.P: $181{ }^{\circ} \mathrm{C}$; IR (KBr) $v_{\max } \mathrm{cm}^{-1}: 3345,1600,888 ;{ }^{1} \mathrm{H}-\mathrm{NMR}$ $\left(300 \mathrm{MHz} \mathrm{CDCl}_{3}\right.$,) $\delta:(J$ in Hz) $12.61(\mathrm{OH}), 6.61(\mathrm{~s}, \mathrm{H}$, H-3), 7.88 (d, twoH, $J=10.0 \mathrm{~Hz}, \mathrm{H}-2^{\prime} 6^{\prime}$ ), 7.03 (d, twoH, $\left.J=10.2,3.0, \mathrm{H}-3^{\prime} 5^{\prime}\right), 3.94,3.91,3.86,3.85$ (s, each tweleveH, -OCH3-6, 7, 8, 4').

5-Hydroxy-3',4',6,7,8-pentamethoxyflavone (6). EIMS $m / z$ : 388; HREI-MS $m / z$ : 388.1153 (calcud. for $\left.\mathrm{C}_{20} \mathrm{H}_{20} \mathrm{O}_{8}, 388.1158\right)$. Light yellowish crystal; $(25 \mathrm{mg})$; M.P: $146{ }^{\circ} \mathrm{C}$; IR $(\mathrm{KBr}) v_{\max } \mathrm{cm}^{-1}: 3511,1681,1575 ;{ }^{1} \mathrm{H}-$ NMR (500 MHz $\mathrm{C}_{5} \mathrm{D}_{5} \mathrm{~N}$,) $\delta$ : $(J$ in Hz) $13.26(5-\mathrm{OH}) 6.85$ (s, H, H-3), 7.87 (d, H, $\left.J=2.1, \mathrm{H}-2^{\prime}\right), 7.11$ (d, H, $J=$ 8.6, H-5'), 7.92 (dd,H, $\left.J=8.5,2.0 \mathrm{~Hz}, \mathrm{H}-6^{\prime}\right), 3.58,3.99$, $3.83 \times 3,4.00,\left(15 \mathrm{H}, \mathrm{s},-\mathrm{OCH} 3-6,7,8,3^{\prime}, 4^{\prime}\right)$.

Apigenin (4',5,7-trihydroxyflavone)(7). EI-MS $\mathrm{m} / \mathrm{z}$ : 270; HREI-MS: $m / z 270.0525$ [M] (calcud. for $\mathrm{C}_{15} \mathrm{H}_{10} \mathrm{O}_{5}$,
270.0527). Yellow powder (35 mg) Melting point: 314 ${ }^{\circ} \mathrm{C}$; UV(MeOH) 338, 266, 214; IR (KBr) $v_{\max } \mathrm{cm}^{-1}$ : 3416, 1670, $16101179 ;{ }^{1} \mathrm{H}-\mathrm{NMR}\left(500 \mathrm{MHz} \mathrm{C}_{5} \mathrm{D}_{5} \mathrm{~N}\right.$,)

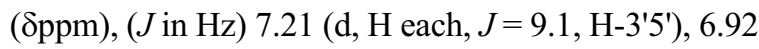
(s, H, H-3), 7.91 (d, H each, $J=9.2, \mathrm{H}^{2} \mathbf{6}^{\prime}$ ) 6.81 (d, $1 \mathrm{H}, J=2.1, \mathrm{H}-8), 6.75$ (1H, d, $J=2.0, \mathrm{H}-6)$.

Luteolin (3',4',5,7-tetrahydroxyflavone) (8). EI-MS $m / z$ : 286; HREI-MS: $m / z 286.0475[\mathrm{M}]^{+}$(calcud. for $\left.\mathrm{C}_{15} \mathrm{H}_{10} \mathrm{O}_{6}, 286.0469\right)$. Light yellow powder $(21 \mathrm{mg})$; Melting point: $324^{\circ} \mathrm{C}$;UV (MeOH)351, 259, 211; IR (KBr) $\cup_{\max } \mathrm{cm}^{-1}: 3426,1674,1607 ;{ }^{1} \mathrm{H}-\mathrm{NMR},(300 \mathrm{MHz}$ ( $\left.\mathrm{CD}_{3} \mathrm{OD}\right)(\delta \mathrm{ppm})$ : $(J$ in $\mathrm{Hz}) 7.37$ (dd, $\mathrm{H}, J=9.1,2.2$, H-2'), 6.87 (d, H, $\left.J=9.1, \mathrm{H}-3^{\prime}\right), 7.39$ (d,H, $J=2.1 \mathrm{H}-$ 6'), $6.52(\mathrm{~s}, 1 \mathrm{H}), 6.41(\mathrm{~d}, \mathrm{H}, J=2.2, \mathrm{H}-8), 6.75(\mathrm{~d}, \mathrm{H}$, $J=2.2, \mathrm{H}-6$ ).

Apigenin 7-O- $\beta$-D-glucopyranose (9). EI-MSm/z: 270 [M-glucose] $^{+}$; HRFAB-MS: $m / z$ 433.1139 [M+H] $]^{+}$ (calcud. for $\left.\mathrm{C}_{21} \mathrm{H}_{21} \mathrm{O}_{10}, 433.1128\right)$. Pale Yellow (30 mg); Melting point: $228^{\circ} \mathrm{C}$; UV(MeOH) 337, 265, 215; IR (KBr) $\cup_{\max } \mathrm{cm}^{-1}: 3425,1668,1637,1618 ;{ }^{1} \mathrm{H}$ NMR (500 $\mathrm{MHz} \mathrm{C}_{5} \mathrm{D}_{5} \mathrm{~N}$, ) $(\delta \mathrm{ppm}):(J$ in $\mathrm{Hz}) 7.21$ (d, H each, $J=$ 9.1, H-3'5'), 7.86 (d, H each, $\left.J=9.1, \mathrm{H}-2^{\prime} 6^{\prime}\right), 7.08$ (d, $\mathrm{H}, J=2.1, \mathrm{H}-8), 6.88$ (s, H, H-3), 6.84 (d, H, $J=2.1$, H-6), 5.85 (d, H, $J=7.5, \mathrm{H}-1$ "), 4.57 (dd,H, $J=1.6$, 1.6, H -6"), 4.37 (dd, H, J = 1.6, 1.6, H -6"), 4.40 (H, m, H -3"), 4.35 (m, H, H -2"); 4.23 (m, H, H -5"), 4.35 $(\mathrm{m}, \mathrm{H})$.

4'-Methyl Kaempferol (3,5,6-trihydroxy-4methoxy flavone) (10). El-MS $\mathrm{m} / \mathrm{z}$ : 300.2; HREI-MS: $\mathrm{m} / \mathrm{z}$ 300.0541 (calcud. for $\mathrm{C}_{16} \mathrm{H}_{12} \mathrm{O}_{6} ; 300.0634$ ). White crystals (18 mg); M.P $227^{\circ} \mathrm{C}$; UV (MeOH): 287, 327; ${ }^{1} \mathrm{H}-\mathrm{NMR}\left(500 \mathrm{MHz} \mathrm{CDCl}_{3},\right) \delta$ : $(J$ in $\mathrm{Hz}) 3.92(\mathrm{~s}$, threeH, $\left.\mathrm{OCH}_{3}\right) 7.25$ (d, twoH, 9.1, H-3', 5'), 7.95 (d, twoH, 9.1, H-2', 6'),6.94 (br.s, H, H-8), 6.87 (br. s, H, H-6).

5-Hydroxy-7, 4'-dimethoxy flavones (11). HREIMS; /z 298.0625 (calcud. for $\mathrm{C}_{17} \mathrm{H}_{14} \mathrm{O}_{5}, 298.0839$ ), Yellow solid (26 mg); M.P. $174{ }^{\circ} \mathrm{C}$; UV (MeOH): 270, 328; ${ }^{1} \mathrm{H}-\mathrm{NMR}$ $\left(400 \mathrm{MHz} \mathrm{CDCl}_{3},\right) \delta:(J$ in $\mathrm{Hz}) 3.87\left(\mathrm{~s}, 3 \mathrm{H}, \mathrm{OCH}_{3}\right.$ at $\mathrm{C}-7)$ and $3.86\left(\mathrm{~s}, 3 \mathrm{H}, \mathrm{OCH}_{3}\right) ; 7.25(\mathrm{~d}, \mathrm{H}, J=9.2, \mathrm{H}-$ 2',6'), 7.01 (d, twoH, $J=9.1$, H-3',5'), 6.57 (s, H, H-3), 6.45 (d,H, $J=2.1, \mathrm{H}-8), 6.35$ (d, H, $J=2.1, \mathrm{H}-6$ ).

6, 7-Dimethoxy-4',5-hydroxyflavone (12). EI-MS $\mathrm{m} / \mathrm{z}$ : 314; HREI-MS: $m / z 314.0769$ [M] $^{+}$(calcud. for $\left.\mathrm{C}_{17} \mathrm{H}_{14} \mathrm{O}_{6} ; 314.0788\right)$. Yellowish crystals (15 mg); M.P. $201{ }^{\circ} \mathrm{C}$; UV (MeOH): 215, 274, 343; IR (KBr) $v_{\max }$ $\mathrm{cm}^{-1}: 3456,1671,1182 ;{ }^{1} \mathrm{H}-\mathrm{NMR}\left(400 \mathrm{MHz} \mathrm{CDCl}_{3}\right.$, ) $\delta:(J$ in $\mathrm{Hz}) 3.99$ (threeH, $s, \mathrm{OMe}), 3.87$ (3H, $s, \mathrm{OMe})$ 

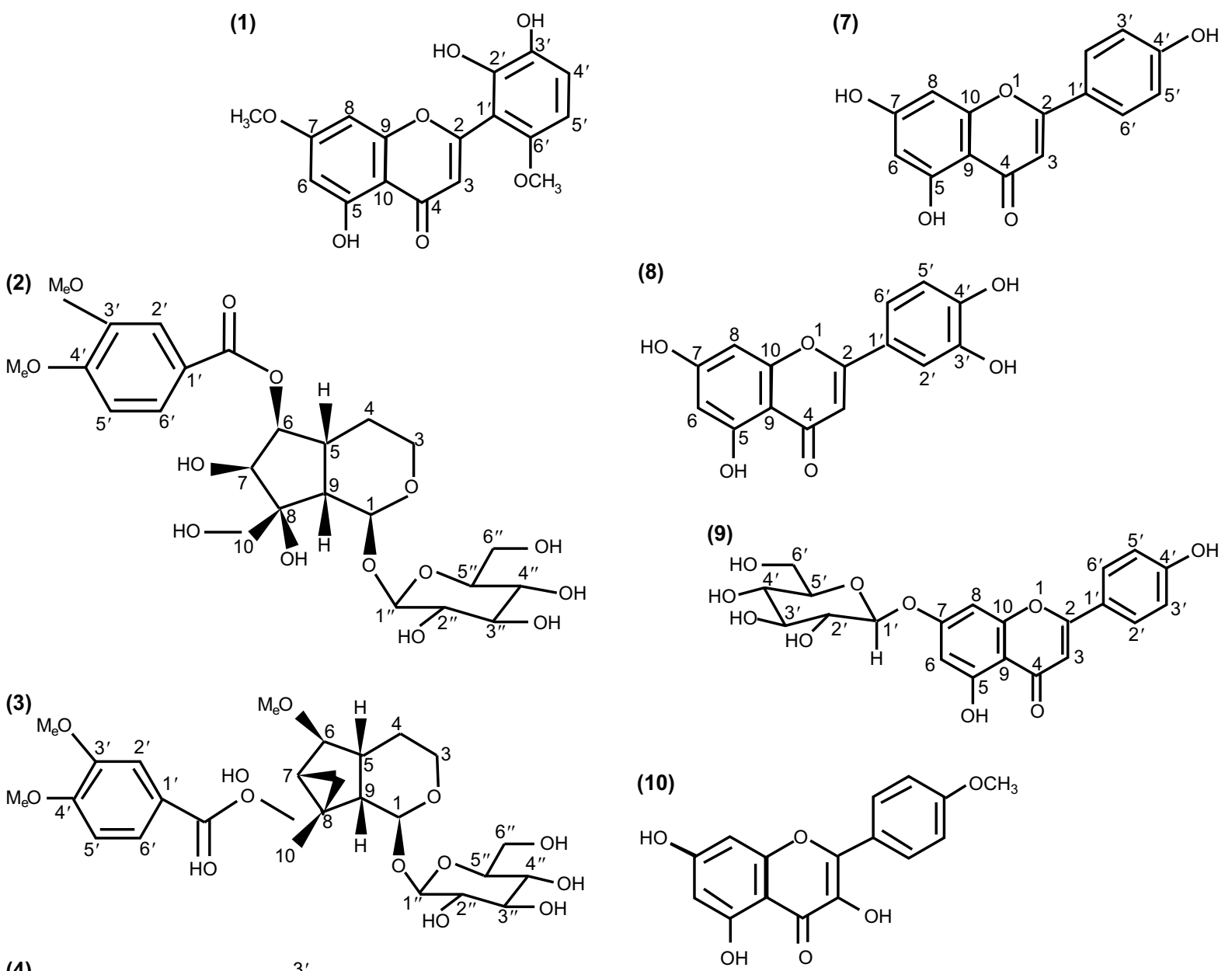<smiles>O=c1c(O)c(-c2ccc(O)cc2)oc2cc(O)cc(O)c12</smiles><smiles>COc1ccc(C2CC(=O)C3C(O)C(OC)C(O)C(C)C3O2)cc1</smiles><smiles>COc1ccc(-c2cc(=O)c3c(O)cc(OC)cc3o2)cc1</smiles><smiles>COc1ccc(-c2cc(=O)c3c(O)c(OC)c(OC)c(OC)c3o2)cc1OC</smiles><smiles>C=C1CC([C]2CCC(O)CC2)[C]c2cc(O)c(O)c(O)c21</smiles>

Scheme 1. Structures of Isolated Compounds (1-13). 
7.02 (twoH, $\left.d, J=8.8, \mathrm{H}-3^{\prime}, 5^{\prime}\right) 7.83$ (twoH, $\left.d, \mathrm{H}-2^{\prime}, 6^{\prime}\right)$ and 6.58 (twoH, $s, \mathrm{H}-8, \mathrm{H}-3$ ).

3,5,7-Trihydroxy-3',4'-dimethoxyflavone (13). EI-MS m/z: 330; HR-EI-MS m/z: 330.0741 (calcud for $\mathrm{C}_{17} \mathrm{H}_{14} \mathrm{O}_{7}$, 330.0739). Yellow powder $933 \mathrm{mg}$; UV (MeOH): 269 and 370; IR (KBr) $v_{\max } \mathrm{cm}^{-1}: 3275,1651,1609$ and 867; ${ }^{1} \mathrm{H}-\mathrm{NMR}\left(300 \mathrm{MHz} \mathrm{CDCl}_{3}\right.$,): $\delta$ : $(\mathrm{J}$ in $\mathrm{Hz}) 3.85$ (threeH, s, OMe), 3.74 (threeH, s, OMe); 7.65(d, H, $J=1.9 \mathrm{H}-$ 2'), 7.60 (dd, H, H-6'), 6.35 (d,H, $J=2.2, \mathrm{H}-8$ ), 6.19 (d, H, $J=2.2 \mathrm{H}-6$ ) and 6.84 (d, H, $\left.J=8.7, \mathrm{H}-5^{\prime}\right)$.

\section{Conclusion}

Bioassy guided separation of secondary metabolites freshly collected from Eremostachys loasifolia plant was carried out first time with the aid of advanced chromatographic and spectroscopic techniques. This study gives thirteen mostly flavonoids metabolites showing significant antioxidant activity. All physical and spectral data of isolated compounds were comparable with already reported structures. This study opens window of opportunity for further studies of medicinal purpose of the plant Eremostachys loasifolia.

\section{References}

Ahmed, E., Imran, M., Malik, A., Ashraf, M. 2006. Antioxidant activity with flavonoidal constituents from Aerva persica. Archives of Pharmacal Research, 29: 343-347.

Ali, S.I., Nasir, Y.J. 1990. Flora of Pakistan, Department of Botany, University of Karachi, vol. 102, pp. 139-141.

Dawson, R.M., Jarvis, M.W., Jefferies, P.R., Panc, T.G., Rosich, R.S. 1966. Acidic constituents of Dodonaea lobulata. Australian Journal of Chemistry, 19: 2133-2142.

Delazar, A., Gibbons, S., Kumarasamy, Y., Nahar, L., Shoeb, M., Sarker, S.D. 2004a. Antioxidant phenylethanoid glycosides from the rhizomes of Eremostachys glabra (Lamiaceae). Biochemical Systematics and Ecology, 33: 87-90.

Delazar, A., Shoeb, M., Kumarasamy, Y., Byres, M., Nahar, L., Modarresi, M., Sarker, S.D. 2004b. Two bioactive ferulic acid derivatives from Eremostachys glabra. DARU Journal of Pharmaceutical Sciences, 12: 49-53.
Imran, M., Mehmood, R., Mughal, U.R., Ali, B., Malik, A. 2012. Vicarin, a new isoflavone from Eremostachys vicaryi. Journal of Asian Natural Products Research, 14: 293-296.

Li, X.W., Hedge, I.C. 1995. Flora of China, vol. 17, pp. 50, Science Press (Beijing) and Missouri Botanical Garden Press, St. Louis, Missouri, USA.

Modaressi, M., Delazar, A., Nazemiyeh, H., Smith, E., Rahman, M.M., Gibbons, S., Nahar, L., Sarker, S.D. 2009. Antibacterial iridoid glucosides from Eremostachys laciniata. Phytotherapy Research, 23: 99-103.

Mughal, U.R., Fatima, I., Malik, A., Tareen, R.B. 2010. Loasifolin, a new flavonoid from Eremostachys loasifolia. Journal of Asian Natural Products Research, 12: 328-330.

Muhammad, Z., Mushtaq, A., Mir, A.K., Asghar, A. 2006. Pollen pictorial of some medicinal plants from Pakistan. Ethnobotanical Leaflets, 10: 121128.

Radcliffe-Smith, A. 1986. Euphorbia L. In: Flora of Pakistan, E. Nasir and I. Ali (eds.) Shamim Printing Press, Karachi, vol. 172, pp. 1 and 224.

Redaelli, C., Formentini, L., Santaniello, E. 1980. Apigenin 7-glucoside diacetates in ligulate flowers of Matricaria chamomilla. Phytochemistry, 19: 985.

Sadikum, A., Aminah, I., Ismail, N., Ibrahim, P. 1980. Sterols and sterol glycosides from the leaves of Gynura procumbens. Natural Products Science, 2: 19-23.

Said, O., Khalil, K., Fulder, S., Azaizeh, H. 2002. Ethnopharmacological survey of medicinal herbs in Israel, the Golan Heights and the West Bank region. Journal of Ethnopharmacology, 83: 251265.

Wang, L.Y., Wang, N.L., Yao, X.S., Miyata, S., Kitanaka, S. 2003. Euphane and tirucallane triterpenes from the roots of Euphorbia kansui and their in vitro effects on the cell division of Xenopus. Journal of Natural Products, 66: 630.

Yoshikawa, K., Nishimura, N., Bando, S., Arihara, S., Eiko, M., Katayama, S. 2002. New lanostanoids, elfvingic acids A-H, from the fruit body of Elfvingia applanata. Journal of Natural Products, 65: 548552. 